\title{
IMPORT SUBSTITUTION IN RUSSIA'S MANUFACTURING INDUSTRY: A WEAK EFFECT ${ }^{1}$

\author{
A. Kaukin, P. Pavlov
}

Russia's import substitution policy has so far failed to have an across-theboard effect. Only a few industries, such as manufacture of metals, textiles, motor vehicles, have managed to replace some of the imported goods with domestically manufactured products. Russia's economy continues to be heavily depending on imports, including machinery and equipment. Most of the Russian manufacturing sectors are poorly integrated into international valueadded chains, which limits their production volume growth.

There are three key factors in Russia, which can be highlighted as having potential to facilitate the substitution of foreign-made goods with domestically manufactured products:

1. Ruble's devaluation ${ }^{2}$. Industries (such as automotive industry, engineering industry, pharmaceuticals industry, manufacture of electrical equipment) that depend heavily on imported intermediate goods and supply most of their products to the domestic market stand to be hit the hardest by a sliding rouble, whereas export-led industries that are less dependent on imports (such as manufacture of ferrous and non-ferrous metals, chemical and petrochemical industry, manufacture and dressing of leather) stand to benefit from the same ${ }^{3}$.

2. Trade sanctions. Sanctions were imposed against Russia in 2014-2015, covering technology goods and supplies of oil and gas equipment, including equipment for producing offshore oil and gas, as well as Russian defence contractors ${ }^{4}$. Theoretically, the shortage of such equipment in the domestic market could have contributed to producing similar products in Russia. Russia's countersanctions against food imports and special economic measures against Turkey contribute to replacing imported food products and consumer goods. The geopolitics-driven decline in the Russia-Ukraine merchandise trade turnover in 2014-2015 contributed to strengthening the import substitution potential in the metallurgy industry and manufacture of building materials.

3. Purposeful measures by economic authorities. The objectives of stimulating import substitution have recently been in the focus of attention at the top level of Russia's Executive Branch ${ }^{5}$. To date, Russia's Industry and Trade

1 This paper was originally published in Online Monitoring of Russia's Economic Outlook No.3(21).

2 In January-December 2015, the year-over-year real effective ruble exchange rate to foreign currencies lost $16.5 \%$, thus following the trend of 2014, when the rate dropped $8.4 \%$ in January-December. See Basic Derived Indicators of Ruble's Exchange Rate Dynamics in JanuaryDecember2015 // Russia's central bank official website, 6 February 2016 [http://www.cbr.ru/ eng/statistics/print.aspx?file=credit_statistics/ex_rate_ind_15_e.htm\&pid=svs\&sid=analit]

3 Indrisov $\mathrm{G}$. The winners and the losers: the effect of terms of trade changes on Russia's industry // Ekonomicheskoye Razvitiye Rossii. No. 4. 2015. PP. 26-28.

4 EU restrictive measures in response to the crisis in Ukraine // European Council [http:// www.consilium.europa.eu/en/policies/sanctions/ukraine-crisis/]. Ukraine and Russia Sanctions // U.S. Department of State [http://www.state.gov/e/eb/tfs/spi/ukrainerussia/]. Sectoral Sanctions Identifications (SSI) List // US Department of the Treasury, 22.12.2015 [https://www.treasury.gov/ofac/downloads/ssi/ssi.pdf]

5 See, e.g., The materials of a meeting on the development of the petrochemical industry // Official Internet Resources of the President of Russia, 15 October 2013 [http://kremlin.ru/ catalog/keywords/121/events/19420] 
Ministry has developed a package of import substitution action plans embracing the full range of manufacturing sectors ${ }^{1}$. Analysis of the effectiveness of import substitution measures has acquired special importance amid Western sanctions and Russia's countersanctions, as well as the unfolding dynamics of the key macroeconomic indicators ${ }^{2}$.

The recent statistics show (Fig. 1) that import substitution is accelerated most in the automotive industry, where the yearly average share of imports ${ }^{3}$ in 2015 decreased by 22.5 p.p. from 2014, manufacture of motor vehicle parts and accessories (down 5.7 p.p.), metals and metal ores (down 4.5 p.p.), narrow fabrics (down 7.8 p.p.), food products (down 4.1 p.p.).

A sharp decline in the share of imports of the motor vehicles sales turnover was determined by the establishment of assembly factories jointly with foreign partners (e.g. Avtovaz, Sollers). Judging by the dynamics of the share of imported motor vehicle parts (motor vehicle spare details and accessories), the level of localization of these industries continues to grow as well.

The dynamics in the metallurgy industry can possibly be explained by stalled imports of Ukrainian goods that are now replaced (at least in part) by Russia-made products. However, consideration must be given to the fact that production volumes in the metallurgy industry in 2015 declined due to the overall decline of both domestic and foreign demand.

The decline in the share of import of textiles may be associated with both strengthening the appeal of domestic production due to cut costs expressed in dollars (labour costs in particular) and implementing investment projects that contributed to enhancing the effectiveness of such production amid changes in the terms of trade (e.g. Vologda Textiles, Kamyshinsk Textiles, etc.). The factors concerning a weakening rouble and countersanctions explain the decline in the share of imports of the food sales turnover in 2014-2015.

On the other hand, some industries, such as, first of all, the pharmaceutical industry and the manufacture of machinery and equipment (including electrical equipment), appear to face a reverse process to that of import substitution.

Russia's pharmaceutical industry is under hard pressure of its global competitors. The yearly average share of imports of the sales turnover of pharmaceutical and medical goods was significant, varying within a range of $50-60 \%$, in the period between 2010 and 2015, and in 2015 it increased 3.2 p.p. from

1 Russia's Industry and Trade Ministry Executive Order No. 197 dated 29 January 2016 "Concerning the approval of the import substitution action plan for the chemical industry of the Russian Federation, and the annulment of Russia's Industry and Trade Ministry Executive Order of 31 March 2015". Russia's Industry and Trade Ministry Executive Order No. 4129 dated 17 December 2015 "Concerning the amendments to the import substitution action plan in the radio-electronic industry of the Russian Federation approved by Russia's Industry and Trade Ministry dated 31 March 2015 No. 662". Russia's Industry and Trade Ministry Executive Order No. 762 dated 2 April 2015 "Concerning the approval of the sectoral import substitution action plan for the conventional arms industry of the Russian Federation". Russia's Industry and Trade Ministry Executive Order No. 645 dated 31 March 2015 "Concerning the approval of the import substitution action plan for the oil-and-gas machine building industry of the Russian Federation" [http://minpromtorg.gov.ru/docs/], etc.

2 See the list of instructions drafted following evaluation of the effectiveness of measures to accelerate the import substitution process for priority and essential products and technology in the automotive industry // Official Internet Resources of the President of Russia, 18 January 2016 [http://kremlin.ru/catalog/keywords/121/events/51179]

3 The yearly average share of imports is calculated as the arithmetical mean of quarterly shares of imports of the merchandise trade turnover in a given year. 
2014. Hence the rouble devaluation made no contribution to import substitution because there is a wide range of medicaments and medical equipment that Russia cannot replace so far. Nonetheless, the industry may achieve a small increase in the domestic output in the longer term: the rouble's depreciation in 2014-2015 may have an effect over the next 2-3 years because licensing new medicaments is a time-consuming process.

A similar situation was seen in the sector of machinery and equipment, where the yearly average share of imports increased 17.6 p.p. in the period between 2012 and 2015, and it is still premature to interpret the 2015 decline of mere 1.1 p.p. in the yearly average share of imports as reversal of the mid-term trend towards stronger dependence of Russia's manufacturing industry on foreign production of capital goods ${ }^{1}$.

The dynamics of the share of imports of the sales turnover of pharmaceutical goods and investment goods (machinery and equipment) highlights the import substitution issues which have to be addressed: the industries that produce such goods failed to take advantage of improved terms of trade, the fall of the real effective rouble exchange rate in 2014-2015, which, among other things, showed itself in the overall decline in the output of these industries throughout the entire 2015.

All in all, the unfolding situation reveals that the import substitution potential was poorly exploited. Unfortunately, only a few industries took advantage of the presented opportunities to increase the share of locally manufactured products in the domestic market (manufacture of metals and textiles, motor vehicles and motor vehicle parts and accessories). Import substitution processes of the rest of the industries were nearly invisible in 2015.

1 The share of imported electrical equipment in 2015 increased 5.3 p.p. from 2014 (or 10.8 p.p. from 2012). 


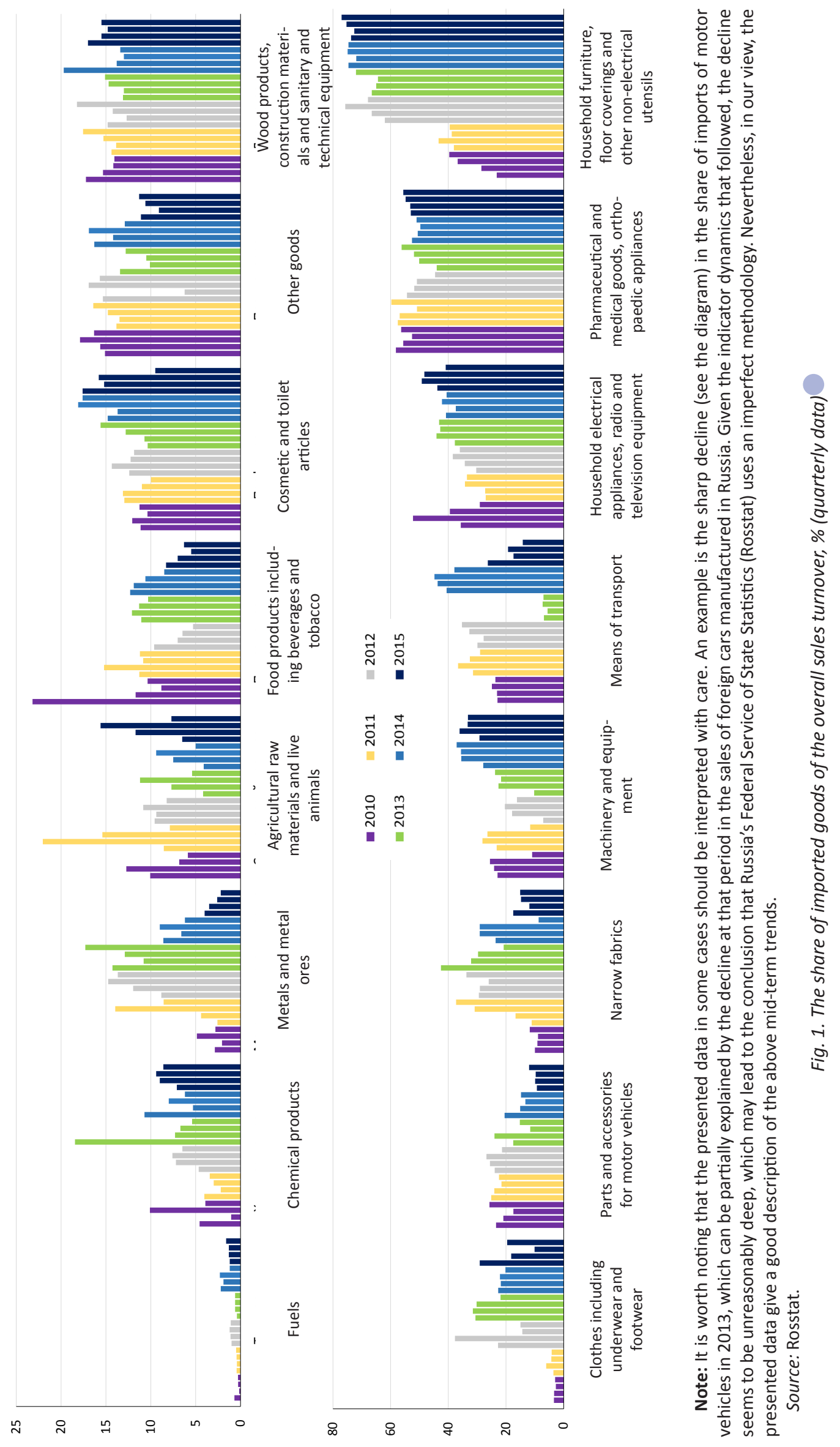

